\title{
Immediate Breast Reconstruction in Large Ptotic Breasts Using the Inferior Based Dermal Flap. Indications and Technique
}

\author{
Maximilian Vlad Muntean', Alex Victor Oradan'*, Alma Andreea Corpodean', Gabriel Lucian Lazar', \\ Vlad Alexandru Gata ${ }^{2}$, Catalin Vlad², Emil Puscas ${ }^{2}$, Ioan Cosmin Lisencu ${ }^{2}$, Patriciu Andrei Achimas-Cadariu ${ }^{2}$ \\ 1Department of Plastic Surgery, "Prof. Dr. I. Chiricuță" Institute of Oncology, "luliu Hațieganu" University of Medicine and Pharmacy, \\ Cluj-Napoca, Romania \\ 2Department of Oncologic Surgery, "Prof. Dr. I. Chiricuță" Institute of Oncology, "luliu Hațieganu" University of Medicine and Pharmacy, \\ Cluj-Napoca, Romania
}

*Corresponding author: Alex Victor Oradan, MD Department of Plastic Surgery

"Prof. Dr. I. Chiricutặ" Institute of Oncology "Iuliu Hatieganu" University of Medicine and Pharmacy

Str. Republicii nr. 34-36, 400015

Cluj-Napoca, Romania

E-mail: alex.oradan@gmail.com
Received: 15.01.2021 Accepted: 13.03.2021

\section{Rezumat \\ Utilizarea lamboului dermal inferior în reconstucția mamară imediată la pacientele cu ptoză majoră. Indicații și tehnică}

Introducere: Reconstrucția imediată cu implant la pacientele cu ptoză mamară semnificativă prezintă numeroase dificultăți tehnice iar rezultatele estetice favorabile sunt greu de obținut. Vă prezentăm filizofia noastră privind reconstrucția mamară la pacientele cu macromastie utilizand lamboul dermal inferior, indicații şi aspecte practice.

Materiale şi Metode: Am realizat mastectomie şi reconstrucție mamară imediată la zece paciente cu ptoză mamară gr. III-IV în cadrul Institutului Oncologic "Prof. Dr. I. Chiricuță" între iunie 2019 şi decembrie 2020. Mastectomia a fost efectuată după un tipar "Wise" iar din pielea restantă a polului inferior mamar a fost deepidermizat un lambou dermal. Lamboul dermal a fost suturat la muschiul pectoral mare pentru realizarea unui buzunar subpectoral complet.

Rezultate: Din totalul de 13 glande mamare reconstruite în 11 cazuri am folosit lambouri dermale pentru realizarea buzunarului subpectoral. Toate procedurile reconstructive au fost finalizate cu succes şi nu au existat pierderi de implant. În patru cazuri (36\%) a apărut o necroză superficială la nivelul lambourilor restante postmastectomie (joncțiune T).

Concluzie:Tehnica lamboului dermal utilizează țesut autolog de la nivelul glandei mamare pentru protejarea implantului. Este o metodă sigură, versatilă şi rapidă care poate fi folosită în numeroase scenarii reconstructive. Lamboul dermal este o metodă ideală de acoperire a implantului în cazul pacientelor cu macromastie. 
Cuvinte cheie: mastectomie, reconstrucție mamară, lambou dermal, macromastie

\begin{abstract}
Introduction: Achieving good aesthetic outcomes during immediate reconstruction in women with large ptotic breast presents a unique challenge for the reconstructive surgeon. We present our paradigm regarding immediate reconstruction in patients with large ptotic breasts, using the inferiorly based dermal flap.

Materials and Methods: Ten patients with large ptotic breasts underwent mastectomy and immediate implant reconstruction at the "Prof. Dr. I. Chiricuta" Institute of Oncology. The mastec" tomy was carried out using a Wise pattern skin resection with preservation of a dermal flap at the lower pole of the breast. The flap was sutured to the pectoralis major muscle and completed the subpectoral pocket created for the implant.

Results: The reconstruction was done bilaterally in three cases with a total number of 13 reconstructed breasts. Of these 11 required dermal flaps. All reconstructions were completed successfully and there were no implant losses. Four breasts (36\%) developed superficial necrosis of the tip of the mastectomy flaps at the T junction.

Conclusion: The dermal flap technique is safe, versatile and reliable. It is used in a wide array of reconstructive scenarios as it provides the surgeon with an excellent alternative to more costly and unreliable methods.
\end{abstract}

Key words: mastectomy, breast reconstruction, dermal flap, ptotic breasts

\section{Introduction}

Breast cancer incidence has continuously risen over the last decades (1), with some studies suggesting that as many as 1 in 8 women will develop breast cancer during their lifetime. The higher sensitivity of diagnostic imaging and new genetic studies allow patients to be diagnosed sooner and benefit from less invasive treatments (2). Although breast conserving surgery and mastectomies have similar outcomes in terms of survival (3), superior aesthetic outcomes have determined more and more patients to incline towards mastectomy and immediate reconstruction (4). Immediate breast reconstruction is an ideal procedure because it does not delay adjuvant treatment (5), oncologic outcomes are unaffected, and patients do not have to deal with the stress and anxiety that follows mastectomy (6).

Achieving good aesthetic outcomes during immediate reconstruction in women with large ptotic breast presents a unique challenge for the reconstructive surgeon. The large and poorly perfused flaps that remain after mastectomy are prone to necrosis and dehiscence so obtaining good implant coverage and protection is paramount.

The original technique of covering the implant using a deepithelialized skin flap from the lower pole of the breast was originally described by Bostwick (7) in 1990 and has suffered various technical modifications since $(8,9)$. We present our philosophy regarding immediate reconstruction in patients with large ptotic breasts. The aim of the paper is to outline the indications and practical aspects of the technique while demonstrating the utility of the method in preventing immediate breast reconstruction complications in this patient group.

\section{Materials and Methods}

\section{Patients}

To qualify for dermal flap breast reconstruction patients have to meet certain criteria. A clear 
indication for mastectomy has to be established and the patient must be able to undergo immediate reconstruction. Patients with either macromastia or grade II or III breast ptosis that require skin or NAC sparing mastectomy and would otherwise be unsuited for immediate reconstruction with implants are the ideal candidates. The technique can be used in patients with lesser degrees of breast ptosis as long as the nipple to inframammary fold (N-F) distance is more than $10 \mathrm{~cm}$. This is because the $\mathrm{N}-\mathrm{F}$ distance represents the maximum height of the dermal flap. The patients in our group were selected from the total number of patients presenting to the plastic surgery unit of IOCN for mastectomy and immediate breast reconstruction over a period of 18 months. To be included all patients had to have grade II or higher breast ptosis, and clear indication for mastectomy and immediate implant based breast reconstruction. Over the above mentioned period 10 patients fulfilled the criteria and benefited from dermal flap breast reconstruction.

Patients were informed about the risks, benefits, and alternatives of the procedure. Written consent concerning the procedure and the subsequent use of intraoperative/perioperative photography was obtained prior to surgery in all cases.

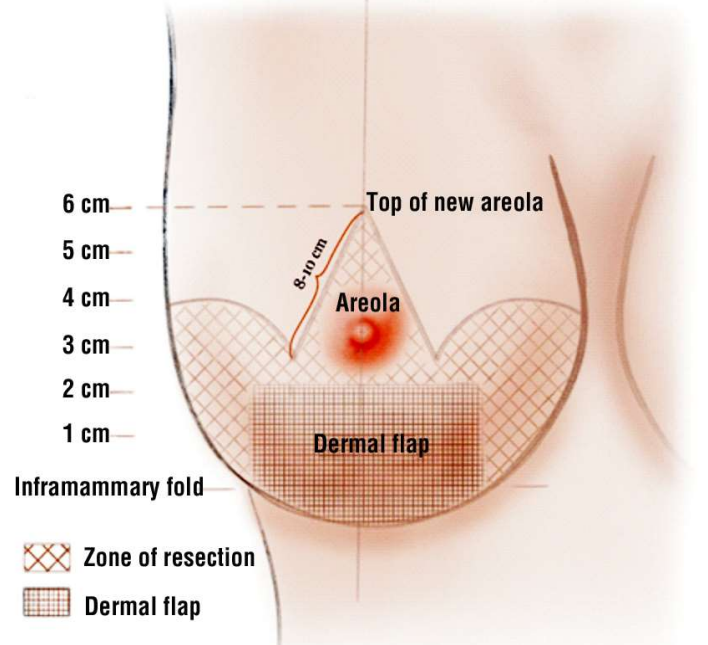

Figure 1. Design and marking of the dermal flap and mastectomy pattern (details in text)

\section{Technique}

Standard photographs are taken before marking the patient.

\section{Markings}

The markings (Fig. 1) are done with the patient standing with both arms at the sides. The breast is inspected for any previous procedures as any scar at the level of the inframammary fold (IMF) or breast lower pole would make the dermal flap unusable. The breast meridian is marked in the center of the breast with disregard for nipple position. If the mastectomy is unilateral the contralateral meridian is mirrored on the breast and in bilateral cases symmetric meridians are drawn on both breasts. A vertical line is drawn from the jugular notch to the xyphoid and another vertical line is drawn at the level of the anterior axillary line. The inframammary fold is marked connecting the two vertical lines previously drawn.

The fold is projected at the level of the sternum and $6 \mathrm{~cm}$ are measured from that point upwards. The $6 \mathrm{~cm}$ mark will be the top of the new areola. The average sternal notch to nipple distance is $21 \mathrm{~cm}$ but there are many variations. The position of the proposed NAC can be checked against the midpoint of the humerus and has to be aesthetically pleasing to the surgeon.

Once the NAC position is marked on the breast meridian two vertical lines are drawn from this point down towards the IMF. These lateral and medial lines will be the new breast pillars. They are drawn by displacing the breast both medially and laterally and aligning the pillars with the superior and inferior part of the breast meridian. The amount of displacement is consistent with the size of the desired reconstruction. The length of the new pillars measured from the top of the areola has to take into account the size of the areola $(\cong 4 \mathrm{~cm})$ so for a medium sized reconstruction with a lower pole distance of around $6 \mathrm{~cm}$ the pillars would measure $10 \mathrm{~cm}$. If the implant has already been selected, the 
distance from the maximum projection point of the implant and the fold can also be used to guide pillar measurement.

From the base of the lateral breast pillar an arc is drawn connecting this point to the lateral aspect of the IMF. This line is tapered according to the size of the breast and meets the IMF somewhere medial to the anterior axillary line. The same process is repeated on the medial side with care not to reach the sternum.

Extending from the IMF to the bottom of the existing areola the dermal flap is marked on the skin centered on the breast meridian. The width of the flap is around $12 \mathrm{~cm}$ but this can be adjusted to accommodate local conditions.

The only skin that is removed during mastectomy is the area between the breast pillars, the dermal flap and the IMF. The existing areola is found somewhere in this area and it can be removed with the breast specimen or taken as a free graft depending on the patients oncologic status.

\section{Surgical Technique}

The general surgery team begins the procedure. The patient is prepared and draped for surgery in standard fashion. The surgery begins by incising the skin around the area proposed for resection. If the nipple will be taken as a free graft this can be done at this time otherwise it is included with the specimen. The mastectomy flaps are elevated at the level of the superficial fascia and down to the pectoral fascia. Special attention is required when elevating the breast from the IMF. No undermining of the IMF is done at the level of the dermal flap in order to maintain maximum blood supply. Once the pectoral fascia is reached the mastectomy specimen is removed along with it. Any other procedures (Lymphadenectomy, SLNB) can be done at this time. Hemostasis is achieved and the patient is re-draped. The plastic surgery team begins the reconstruction. No adrenaline is infiltrated prior to de-epithelization to avoid damaging the vessels. The subdermal flap is deepithelialized above the subdermal plexus (Fig: 2).

A subpectoral pocket is created by elevating the pectoral muscle and dividing its costal attachments all along the IMF up to the sternal border. The serratus fascia is raised al the lateral end of the pocket and the selected breast implant is inserted under the pectoralis muscle (Fig. 3). Anatomically shaped, round base polyurethan implants (Replicon ${ }^{\circledR}$, Microthane $^{\circledR}$, Polytech, Dieburg, Germany) were used in all cases. The subdermal flap is tailored as needed and then sutured to the pectoralis major and laterally to the serratus fascia. Total submuscular coverage is achieved (Fig. 4).

Two drains are placed, one inside the pocket and another overlying pectoralis major. The lateral and medial breast pillars are sutured together and fixed at the IMF along the breast meridian using a $2 / 0$ vicryl suture. This is the key suture at the $\mathrm{T}$ juncture and here is where most of the breakdowns occur. Care must be taken not to damage the tips of the flaps when

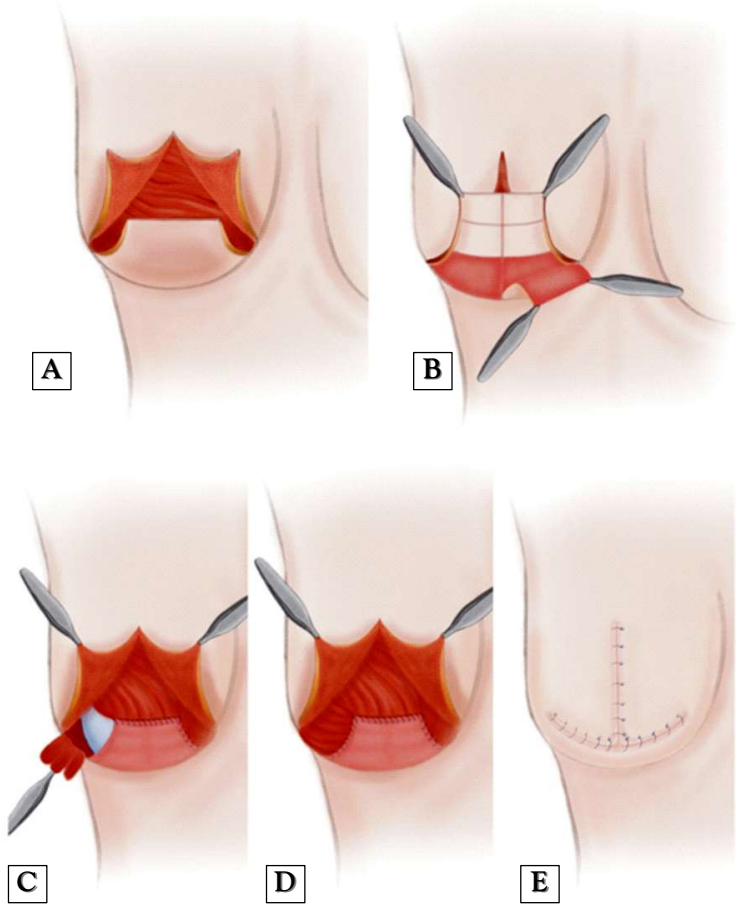

Figure 2. Deepithelialization of the dermal flap and creation of the implant pocket with total implant coverage

(A) redundant skin flaps after mastectomy; (B) deeithelization of skin flaps; (C) suturing the flap to pectoralis major; (D) completion of the subpectoral pocket; (E) final result 
Figure 3. Dermal flap creation

(A) mastectomy skin flaps;

(B) breast lower pole skin flap;

(C) deepidermization of the dermal flap;

(D) final aspect
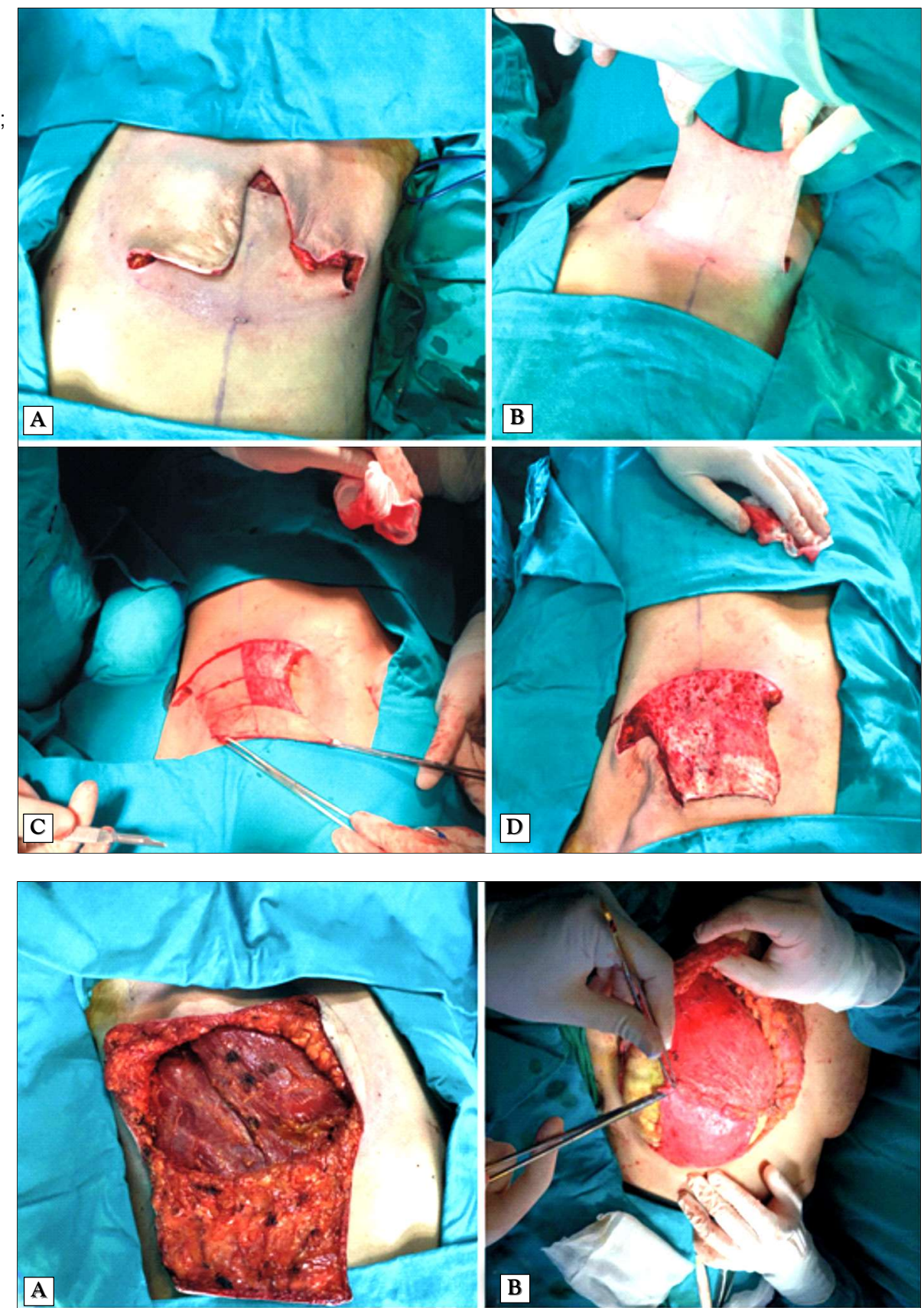

Figure 4. Total submuscular coverage using the dermal flap

(A) Pectoralis m., serratus and dermal flap at the end of the mastectomy; (B) dermal flap sutured to pectoralis m. muscle; (C) complete muscle coverage using the dermal flap, pectoralis $m$. and serratus fascia; (D) final on table result after draping if the skin flaps
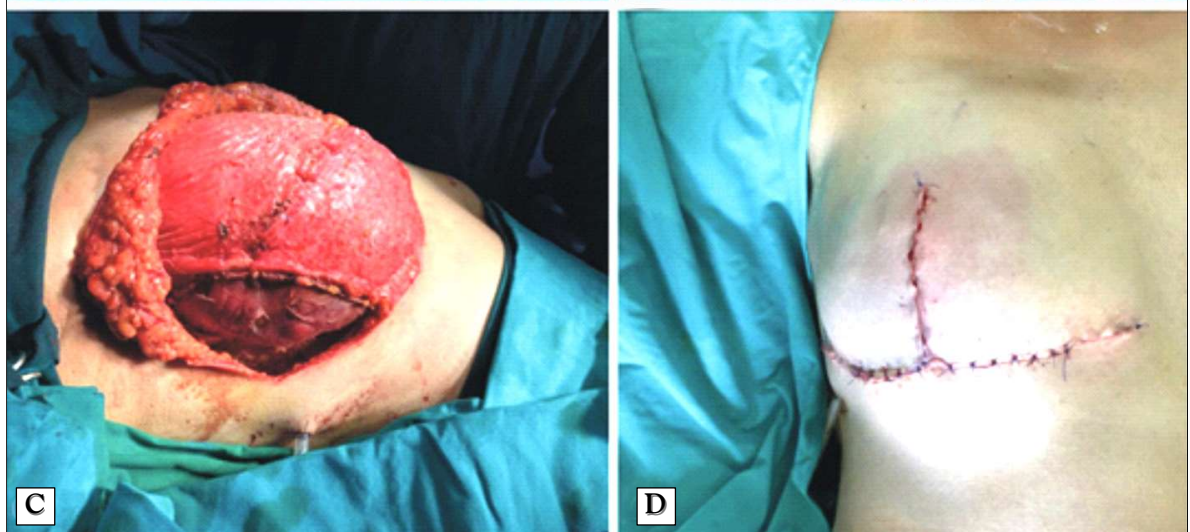
anchoring them to the IMF. Symmetry is checked and any further adjustments to the position of the implant and skin flaps can be made at this time. The breast flaps are draped over the implant and skin suture is done using 2/0.3/0 and 4/0 absorbable sutures, with the final closure being intradermal. If the nipple has been taken as a graft, the area corresponding to the new NAC is deepithelialized and the nipple graft is sutured into position using nonabsorbable 5/0 sutures. The graft is covered with Vaseline gauze and a compressive dressing. The sutures are covered with sterile strips and dressings. Drains are checked and the patient is transferred to post anesthesia care unit.

\section{Postoperative Care}

Skin flaps are inspected and monitored closely during the first postoperative day. Care is taken that nothing (hematoma, dressing, patient position) interferes with skin flap vascularization. The patient receives IV antibiotic medication, usually ceftriaxone $1 \mathrm{~g}$ twice daily during hospital admission and then will continue oral antibiotic medication at home until drain removal. Drains are removed when the output drops under $30 \mathrm{ml} / 24 \mathrm{~h}$ for two consecutive days . After confirming skin flap survival the patient receives a supportive bra and wears this for at least 2 months. Sutures are removed at 14 days post-op and the patient is scheduled for check-ups at 1,3 and 12 months.

\section{Results}

From June 2019 till December 202010 patients with large ptotic breasts underwent mastectomy and immediate reconstruction at the "Prof. Dr. I. Chiricuta" Institute of Oncology. One case was purely prophylactic, two cases were therapeutic/prophylactic and the rest were therapeutic for breast cancer. Three cases were bilateral with a total number of 13 reconstructed breasts (Table 1). A total of 11 breast reconstructions with dermal flaps were done. The other two breasts were secondary cases and received autologous reconstruction with DIEP and latissimus dorsi flap and implant. Average hospital stay was 9 days (7-15 days). Anatomic round base polyurethan implants were used in all cases. The average implant volume was $410 \mathrm{ml}$ (350$435 \mathrm{ml}$ ). A free nipple graft was taken in one bilateral case with good subsequent graft vascularization and integration. The rest have or will undergo NAC reconstruction. All reconstructions were completed successfully and there were no implant losses. One patient developed a hematoma on the second post-

Table 1. Dermal flap breast reconstruction patient series

\begin{tabular}{|c|c|c|c|c|c|c|c|c|c|c|}
\hline & Patient & Age & Mastectomy & $\begin{array}{l}\text { Reasons for } \\
\text { surgery }\end{array}$ & Chemotherapy & Radiotherapy & Side & $\begin{array}{l}\text { Implant } \\
\text { size }(\mathrm{ml})\end{array}$ & $\begin{array}{l}\text { Days in } \\
\text { hospital }\end{array}$ & Complications \\
\hline 1 & $\mathrm{BM}$ & 38 & $\begin{array}{c}\text { Bilateral + } \\
\text { R axilla }\end{array}$ & $\begin{array}{l}\text { Therapeutic/ } \\
\text { Prophilactic }\end{array}$ & No & No & Bilateral & $420 / 420$ & 11 & Hematoma \\
\hline 2 & $\mathrm{MF}$ & 31 & Unilateral & Therapeutic & Yes & No & $L$ & 425 & 7 & $\begin{array}{c}\text { Partial necrosis } \\
\text { of the tip }\end{array}$ \\
\hline 3 & $\mathrm{Gl}$ & 34 & $\begin{array}{c}\text { Unilateral + } \\
\text { axilla }\end{array}$ & Therapeutic & No & No & $\mathrm{R}$ & 435 & 9 & $\begin{array}{c}\text { Partial necrosis } \\
\text { of the tip }\end{array}$ \\
\hline 4 & $\mathrm{DA}$ & 41 & Unilateral & Therapeutic & Yes & No & L & 350 & 15 & None \\
\hline 5 & LE & 38 & Unilateral & Therapeutic & Yes & No & $\mathrm{L}$ & 445 & 7 & None \\
\hline 6 & SA & 33 & Bilateral & Prophilactic & No & No & Bilateral & $395 / 395$ & 10 & $\begin{array}{c}\text { Partial necrosis } \\
\text { of the tip }\end{array}$ \\
\hline 7 & II & 45 & Unilateral & Therapeutic & Yes & No & $L$ & 425 & 8 & None \\
\hline 8 & CV & 48 & Unilateral & Therapeutic & Yes & Yes & $\mathrm{R}$ & 395 & 6 & None \\
\hline 9 & $\mathrm{TA}$ & 39 & Bilateral & $\begin{array}{l}\text { Therapeutic/ } \\
\text { Prophilactic }\end{array}$ & No & No & Bilateral & $330 / 330$ & 11 & $\begin{array}{c}\text { Partial necrosis } \\
\text { of the tip }\end{array}$ \\
\hline 10 & SN & 49 & Unilateral & Therapeutic & No & No & $\mathrm{R}$ & 395 & 7 & None \\
\hline
\end{tabular}


Figure 5. Before and after result after mastectomy and immediate dermal flap and implant breast reconstruction using implant and dermal flap on the left side and latissimus dorsi and implant secondary breast reconstruction on the right side

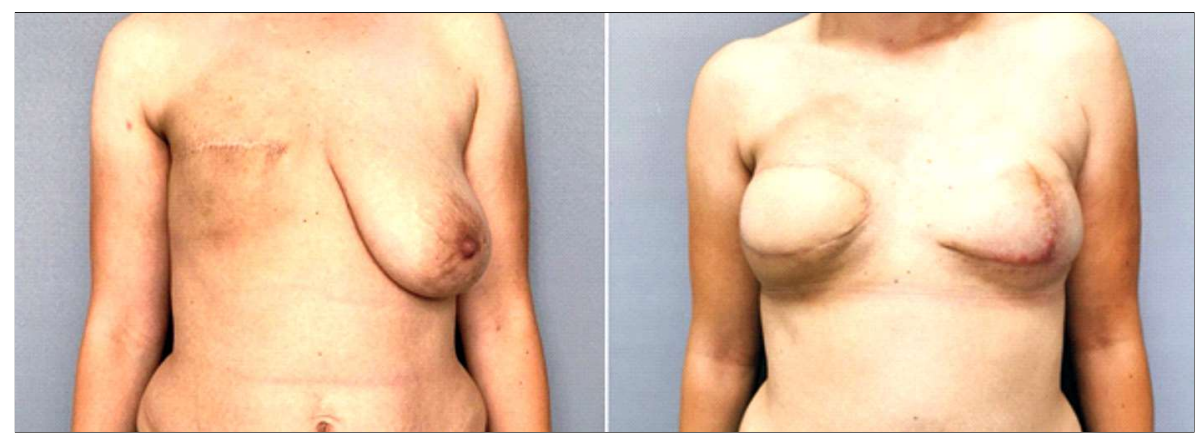

operative day and required reintervention for drainage and hemostasis and went on to heal uneventfully. Four breasts (36\%) developed superficial necrosis of the tip of the mastectomy flaps at the $\mathrm{T}$ junction. The wounds granulated and eventually epithelialized with conservative wound care (Fig. 5). One patient received adjuvant radiotherapy with no complications.

\section{Discussions}

Immediate breast reconstruction in patients with macromastia or severe ptosis is a challenging procedure and good aesthetic outcomes are hard to achieve. Because the redundant mastectomy flaps have poor perfusion, breakdowns at the $\mathrm{T}$ junction are common even in experienced hands. Dehiscence occurs in up to $25 \%$ of Wise pattern mastectomies (10). This high complication rate can lead to implant exposure and subsequent infection, compromising the reconstruction. To prevent this the $\mathrm{T}$ junction must be protected and the implant completely covered $(11,12)$.

Implant coverage using a dermal flap from the lower pole of the breast is not a new concept. The use of deepithelialized breast flaps to cover and support the breast has been described by numerous authors (13-16) and the technique is used in both reconstructive and aesthetic cases. In aesthetic surgery dermal flaps are used mainly to prevent implant migration and malposition (17) while in reconstructive cases they provide stable implant coverage immediately after surgery and during radiotherapy $(18,19)$. Implant malposition was not a concern for us because we only use polyurethane implants for breast reconstruction. Although the mastectomy leaves behind a very large pocket, the surface of the Microthane ${ }^{\circledR}$ implant is highly adhesive to tissues making implant displacement impossible (20). Smooth and textured implants lack this feature and have a much higher rate of capsular contracture when compared to polyurethan implants (21).

Because implant stability was not an issue, the dermal flap design in our technique is centered on the breast meridian and does not extend as much laterally as described by other authors (22). Extending the flap laterally is unnecessary as it can cause problems with flap vascularization and has a negative impact on aesthetic breast contour. Using a S shaped incision medially as described by Carstensen (23) allows good coverage of the medial aspect of the implant while the serratus fascia can be raised if there is a need for lateral fixation. This is optional when using polyurethane implants.

The dermal flap provides coverage and protection of the implant at the $\mathrm{T}$ juncture where dehiscence is most common. The thickness of the mastectomy flaps is variable between patients ranging from 1-2 $\mathrm{mm}$ up to 2 $\mathrm{cm}$ (24). The thinner the flap the higher the risk of complications. The incidence of flap necrosis is fairly common, $36 \%$ in our series of patients, but having viable, well vascularized tissue underneath, allows for spontaneous wound healing and epithelization (25). Flap loss leads to implant exposure and implant loss. By using the dermal flap in our series we prevented reintervention and implant loss in 4 breasts. Larger defects can be grafted but all our patients 
healed with conservative wound treatment. Implant coverage is also important in the late postoperative phase if the patients undergo adjuvant radiotherapy. The dermal flap prevents implant exposure while preventing post radiotherapy capsular contracture.

Acellular dermal matrices (ADMs) are soft connective tissue grafts generated trough a process of decellularization that preserves the intact extracellular skin matrix. They provide a scaffold for donor cells to incorporate and revascularize (26). They have been extensively used in breast surgery, mainly for providing lower pole coverage (27). The ADM is sutured to the IMF and then to the pectoralis major creating total coverage of the implant. Using dermal matrices is faster and less technically demanding than creating and tailoring dermal flaps, however there are some drawbacks. Recent data shows that the risk of developing hematomas, seromas and infections is higher in ADM breast reconstructions (28). There is also a risk of immunologic reactions to the matrix (29).

An ADM behaves similar to any nonvascularized graft. Once it is placed on the breast it needs to be integrated and vascularized by the breast flaps. As mentioned earlier the mastectomy flaps in these kinds of patients tend to be poorly vascularized and ischemic. ADMs placed underneath ischemic flaps are not integrated and dissolve leading to wound breakdowns and implant exposure. Another issue with ADM use is financial as these products have very high cost and are not covered by health insurance in our country (30).

The advantages provided by dermal flaps over ADMs are obvious (31), but the main benefit is that of having very well vascularized robust tissue at the $\mathrm{T}$ junction that provides protection immediately and is not dependent on breast flap integration. This is crucial in the immediate postoperative phase when most complications occur. We still use ADMs in patients who do not have enough autologous tissue to create dermal flaps, patients with previous scars at the level of the IMF or in instances where there is an oncologic contraindication (location of the tumor).

Immediate breast reconstruction usually involves two different teams. The general (oncologic) surgery team is responsible for the resection while the plastic surgeons finalize the reconstruction. Communication between the two teams is essential in reconstructions with autologous dermal tissue because great care must be taken during the mastectomy part not to damage the flaps blood supply or to aggressively overthin the flap as this leads to necrosis and reinterventions. In our series we had no instances of flap compromise.

Reconstruction of large ptotic breasts usually requires two stages and an expanderimplant approach (32). This leads to increased costs, longer hospital stays with increased downtime and anxiety for the patients (33). Using autologous dermal flaps we can achieve one stage immediate reconstructions with good cosmetic outcomes and minor complications. By using the dermal flap in our case series we have prevented major complications (implant exposure/implant loss/reintervention) in 4 breasts, accounting for $36 \%$ of cases presented in this group. Our results prove that the technique described has a major impact on both morbidity reduction and the number of reinterventions required. Being able to use inexpensive well vascularized tissue to cover the implant is extremely important in immediate breast reconstruction and this technique provides exactly that.

The small number of patients presented in our group is a limiting factor in establishing statistical significance but the major impact this technique has in reducing complications warrants further study.

\section{Conclusion}

As the number of mastectomies performed for breast cancer and risk reduction continues to rise so do the single stage immediate implant based breast reconstructions. Patients with large, ptotic breast pose a unique challenge for the reconstructive surgeon. The dermal flap technique uses the patient's own tissues as an autologous flap. It can be used during 
immediate implant reconstruction to cover and protect the implant, optimize aesthetic outcomes and reduce costs. The technique is safe, versatile and reliable. It is used in a wide array of reconstructive scenarios as it provides the surgeon with an excellent alternative to more costly and unreliable methods.

\section{Conflict of Interest}

The authors declare no conflicts of interests.

\section{Ethics Approval}

All study participants provided informed consent on admission and all clinical information for each patient was coded; finally, the study was approved by the institutional ethical committee.

\section{Acknowledgements}

All the drawings were made by the author Alma A Corpodean

\section{References}

1. Lima SM, Kehm RD, Swett K, Gonsalves L, Terry MB. Trends in Parity and Breast Cancer Incidence in US Women Younger Than 40 Years From 1935 to 2015. JAMA Network Open. 2020;3(3): e200929-e.

2. Katipamula R, Degnim AC, Hoskin T, Boughey JC, Loprinzi C, Grant CS, et al. Trends in mastectomy rates at the Mayo Clinic Rochester: effect of surgical year and preoperative magnetic resonance imaging. J Clin Oncol. 2009;27(25): 4082-8.

3. McGuire KP, Santillan AA, Kaur P, Meade T, Parbhoo J, Mathias M, et al. Are mastectomies on the rise? A 13-year trend analysis of the selection of mastectomy versus breast conservation therapy in 5865 patients. Ann Surg Oncol. 2009;16(10):2682-90

4. Bhat S, Orucevic A, Woody C, Heidel RE, Bell JL. Evolving Trends and Influencing Factors in Mastectomy Decisions. Am Surg. 2017;83(3): 233-8.

5. Zhang P, Li CZ, Wu CT, Jiao GM, Yan F, Zhu HC, et al. Comparison of immediate breast reconstruction after mastectomy and mastectomy alone for breast cancer: A meta-analysis. Eur J Surg Oncol. 2017; 43(2):285-93.

6. Harcourt D, Rumsey N. Psychological aspects of breast reconstruction: a review of the literature. J Adv Nurs. 2001;35(4):477-87.

7. Bostwick J. Plastic and reconstructive breast surgery: Quality Medical Pub.; 1990.

8. Nava MB, Rocco N, Catanuto G. Conservative mastectomies: an overview. Gland Surg. 2015;4(6):463-6.

9. Vlajcic Z, Martic K, Budi S, Roje Z, Dewing D, Zic R. The "dermal cage": Inferiorly based dermal flap technique for breast reconstruction after mastectomy. J Plast Reconstr Aesthet Surg. 2020;73(3): 486-93.

10. Kilgo MS, Kaufman GJ, Shen AE, Korsh J, Baranchuk NV, Douglas BK, et al. A comparison of elliptical mastectomy to inverted-T pattern mastectomy in twostage prosthetic breast reconstruction. Plast Reconstr Surg. 2015;136(4): 426e-433e.

11. Losken $A$, Collins BA, Carlson GW. Dual-plane prosthetic reconstruction using the modified wise pattern mastectomy and fasciocutaneous flap in women with macromastia. Plast Reconstr Surg. 2010; 126(3):731-738.

12. Ross GL. One stage breast reconstruction following prophylactic mastectomy for ptotic breasts: the inferior dermal flap and implant. J Plast Reconstr Aesthet Surg. 2012;65(9):1204-8.

13. Salim F, Tahir A, Serra MP, Longhi P. The versatility of the inferior dermal flap in implant/expander-based immediate breast reconstruction and its application in augmentation-mastopexy. European Journal of Plastic Surgery. 2010;33(4): 209-13.

14. Tanski EV. A new method for prophylactic mastectomy, reduction mammaplasty, and mastopexy. Plast Reconstr Surg. 1980;65(3): 314-22.

15. Rosato FE, Fink PJ, Horton CE, Payne Jr. RL. Immediate postmastectomy reconstruction. J Surg Oncol. 1976;8(4):277-80.

16. Ladizinsky DA, Sandholm PH, Jewett ST, Shahzad F, Andrews K. Breast reconstruction with the Bostwick autoderm technique. Plast Reconstr Surg. 2013:132(2):261-270.

17. de Vita R, Zoccali G, Buccheri EM. The Balcony Technique of Breast Augmentation and Inverted-T Mastopexy With an Inferior Dermoglandular Flap. Aesthet Surg J. 2017;37(10):1114-1123.

18. Irwin G, Black A, Refsum S, Mclntosh S. Skin-reducing mastectomy and onestage implant reconstruction with a myodermal flap: a safe and effective technique in risk-reducing and therapeutic mastectomy. J Plast Reconstr Aesthet Surg. 2013:66(9):1188-94.

19. Clerico C, Ihrai T, Raoust I, Chignon-Sicard B, Georgiou C, Flipo B, editors. Mastectomy and immediate breast reconstruction using a prosthesis and lower dermal flap: description of five cases. Ann Chir Plast Esthet. 2012;57(6):606-11. French

20. Pompei S, Evangelidou D, Arelli F, Ferrante G. The Modern Polyurethane-Coated Implant in Breast Augmentation: Long-Term Clinical Experience. Aesthet Surg J. 2016:36(10):1124-1129.

21. de la Peña-Salcedo JA, Soto-Miranda MA, Lopez-Salguero JF. Back to the future: a 15-year experience with polyurethane foam-covered breast implants using the partial-subfascial technique. Aesthetic Plast Surg. 2012;36(2):331-8. Epub 2011 Dec 17.

22. Friedman HI, Talebagha S, Gilstrap J, Mujadzic M, Chen E. Wise Pattern Direct Implant Breast Reconstruction: A Review and Improved Outcomes Using Dermal Matrix. Plast Reconstr Surg Glob Open. 2019;7(10):e2439-e.

23. Carstensen L. Visualized immediate breast reconstruction with dermal flap and implant. Gland Surg. 2019:8(Suppl 4):S255-s61.

24. Nava MB, Catanuto G, Rocco N. How to optimize aesthetic outcomes in implantbased breast reconstruction. Arch Plast Surg. 2018:45(1):4-13.

25. King I, Harvey J, Bhaskar P. One-stage breast reconstruction using the inferior dermal flap, implant, and free nipple graft. Aesthetic plastic surgery. 2014;38(2): 358-64.

26. Boháč M, Danišovič L, Koller J, Dragúňová J, Varga I. What happens to an acellular dermal matrix after implantation in the human body? A histological and electron microscopic study. Eur J Histochem. 2018;62(1):2873.

27. Salzberg CA, Ashikari AY, Koch RM, Chabner-Thompson E. An 8-year experience of direct-to-implant immediate breast reconstruction using human acellular dermal matrix (AlloDerm). Plast Reconstr Surg. 2011;127(2):514-24.

28. Zhao X, Wu X, Dong J, Liu Y, Zheng L, Zhang L. A Meta-analysis of Postoperative Complications of Tissue Expander/mplant Breast Reconstruction Using Acellular Dermal Matrix. Aesthetic Plast Surg. 2015:39(6):892-901.

29. Ganske I, Hoyler M, Fox SE, Morris DJ, Lin SJ, Slavin SA. Delayed hypersensitivity reaction to acellular dermal matrix in breast reconstruction: the red breast syndrome? Ann Plast Surg. 2014;73 Suppl 2:S139-43.

30. Filip Cl, Jecan CR, Raducu L, Neagu TP, Florescu IP. Immediate Versus Delayed Breast Reconstruction for Postmastectomy Patients. Controversies and Solutions. Chirurgia (Bucur). 2017; 112(4):378-86.

31. Hon HH, Mubang RN, Wernick BD, Freedman SF, Stoltzfus JC, Miele LF et al. Acellular Dermal Matrix Versus Inferior Deepithelialized Flap Breast Reconstruction: Equivalent Outcomes, with Increased Cost. Plast Reconstr Surg Glob Open. 2017;5(6): e1382.

32. Nahabedian MY. Implant-based breast reconstruction following conservative mastectomy: one-stage vs. two-stage approach. Gland Surg. 2016:5(1):47-54

33. Lee KT, Mun GH. Comparison of one-stage vs two-stage prosthesis-based breast reconstruction: a systematic review and meta-analysis. Am J Surg. 2016; 212(2):336-44 